\author{
В.В. Вишнівський, А.П. Бондарчук, Ю.І. Катков, С.О. Сєрих
}

Державний університет телекомунікащій, Киї

\title{
ОЦІНКА ПРОЦЕСІВ ФУНКЦІОНАЛЬНО-СТРУКТУРНОЇ РЕОРГАНІЗАЦІЇ ОРГАНІЗАЦІЙНО-ТЕХНІЧНОЇ СИСТЕМИ
}

В статті розглядається сутність прочесу реорганізації складної організаційно-технічної системи та питання оцінки адміністративного управління під час виконання задач на всіх етапах ичклу управління установою. Розглядаються аспекти організованості складної організаційно-технічної системи. Пропонуються моделі управління функціонально-структурною реорганізацією системи. Визначаються критеріі організованості під час процесу реорганізаџіï. Обтрунтовується в якості міри організованості складної організаційно-технічної системи - ентропія. Надаються математичні моделі організованості.

Ключові слова: організачійно-технічна система, критична система, управління, виклики, загрози, реорганізація, керованість, ентропія.

\section{Вступ}

В теорії управління складними системами актуальним залишається завдання підвищення ефективності управлінської діяльності складної організаційно-технічної системи (СОТС). В статті під СОТС представлено інформаційну систему. При дослідженні функціонування СОТС встановлено [1], що в системі завжди є критичний елемент, вплив на який з боку виклику або загрози може призвести до критичного стану всієї системи. Така система має назву - організачійна система з критичною інфраструктурою (ОСКІ). Прикладом являється інформаційній вплив через засоби масової інформації на свідомість населення, наприклад, про девальвацію валюти. Чутки можуть призвести до паніки населення і як наслідок воно почне скупати ліквідні товари або іншу валюту і ці дії можуть призвести до обвалу ринку. Для попередження такого кризового стану необхідно виконувати в постійно діючій установі (організації) деякі процеси адаптації до нових та змінних умов, які мають назву реорганізація.

Зазначимо, що реорганізація - це процес поступового перетворення, перебудови, зміни структури і функції установи (організації), злиття, поділ, виділення, перетворення, удосконалення організаційних відношень в постійно діючих структурах цих установ. Це пристосування до умов функціонування, які змінюються одночасно зі змінами в організаційній системі. В [2] раціонально зазначено, що реорганізація є формою системно-процесорного підходу обгрунтування практичної діяльності органів управління з метою попередження критичних ситуацій.

Постановка завдання. Як форма управлінської діяльності, реорганізація здійснюється під час адміністративного управління на різних етапах циклу управління, а саме під час: визначення цілей, планування, організації, активізації, контролювання, координації, регулювання [3]. При цьому в тради- ційній схемі управління виділяють адміністративний орган (адміністратор, менеджер) і виконавчі органи (сили і засоби). Ця схема передбачає наступний алгоритм роботи: вищий орган управління формулює адміністратору завдання $\boldsymbol{A}$ на основі загальної мети. Адміністратор відносно цього завдання $\boldsymbol{A}$ визначає сукупність задач $A_{1}, A_{2}, \ldots A_{k}$, які необхідні для виконання завдання $\boldsymbol{A}$, і здійснює їх розподіл між виконавчими елементами 3 урахуванням їх спроможні одночасно виконувати ці задачі в сукупності із вже існуючими. Безумовно, що результат виконання залежить від дії адміністратора, які треба оцінити. Тому для цього необхідна відповідна модель процесу управління та визначення показників оцінки. Тому виникає питання оцінки адміністративного управління під час реорганізації для виконання задач на етапах циклу управління установою.

Аналіз останніх публікацій. Проблемі синтезу моделей управління та оцінки управлінської діяльності присвячена велика кількість наукових та науково-практичних робіт. В [4-6] розкриті уявлення про сутність управління, пропонуються варіанти різноманітних моделей управління, що мають загальний класичний зміст. В сучасних роботах [7-13] під час оцінки ефективності моделей управління враховуються різні аспекти сутності управління: раціональна діяльність, цілеспрямований вплив, упорядкування, регулювання, оптимізація, а також [9-11] типи управлінської діяльності (евристична, адміністративна, операторна). Проведений аналіз сучасних наукових робіт вказує як на велику складність формалізації самого процесу управління так і розв'язання завдань управління в СОТС. Тому вирішення завдань формалізації процесів реорганізації для ОСКІ, як виду СОТС - це новий, більш складний тип завдань, який обумовлений обмеженням в часі ïx рішення. Він потребує сучасних підходів для синтезу і аналізу інформаційних систем. Тому дане завдання $є$ актуальним та своєчасним. 


\section{Основна частина}

Для вирішення завдань формалізації процесів управління під час реорганізації ОСКІ необхідно розглянути особливості такої управлінської діяльності. Доцільно вважати, що адміністратор для виконання завдання реорганізації, повинен мати модель проиесу управління під час реорганізаџіï.

Першим кроком у створенні такої моделі є визначення різних уявлень про сутність управління під час реорганізації, що мають вплив на адекватність моделі реорганізації. Умовно можна визначити такі аспекти сутності управління під час реорганізації: раціональну або доцільну діяльність, цілеспрямований вплив, упорядкування, регулювання, оптимізацію, які за змістом можна розглядати аналогічно запропонованим в [7-9]. Тобто раціональна діяльність управління під час реорганізації має більш широкий зміст [7]. Якщо увага спрямована до цілеспрямованого впливу, зміст управління під час реорганізації полягає у аналізі окремих дій, які розглядаються, як правило, без урахування того, що попереджує діям або їх наслідкам [12]. Під упорядкуванням [13] розуміється установлення у відношеннях елементів системи заданого порядку (правил). Під регулюванням розглядаються механізми регулюючих впливів, які для соціо, фізичних, технічних та інформаційних систем поділяються на природні і штучні. При цьому, якщо природні регулятори контролюють реакції системи відносно існуючих об'єктивних умов, то штучні регулятори мають достатній ступінь суб'єктивізму, як зазначено в [4], а під оптимізацією управління визначають критерії та обмеження [14].

Дослідження показують, що адекватність моделей управління під час реорганізації залежить, поперше, від чіткого визначення виду та етапу управлінської діяльності в загальному процесі управління, а, по-друге, від сутності управління під час реорганізації, що приймається за основу.

При проведені дослідження загальний процес управління під час реорганізації доцільно розглядати в якості процесу адміністративної діяльності та вважати, що це виконується на етапах організації, активації і координації дії виконавчих елементів, тобто до моменту контролю їх функціонування. Це пов'язано з тим, що реорганізація обумовлена змінами функцій і структури адаптивної частини ОСКІ [15]. Такий період циклу управління визначається як функціонально-структурна реорганізація системи.

Головним, в цьому випадку, являється створення моделі управління функціонально-структурної реорганізації системи і визначення критерію організованості під час реорганізації. Природно, що загальним критерієм всього процесу управління стає якість управління, яка є досить суб'єктивною. Додатково необхідно визначити: які властивості управління характеризують його якість під час функціонально-структурної реорганізації системи для вико- нання завдань. Для цього необхідно розглянути основні умови досягнення загальної мети. Відомо, що загальний процес управління оцінюється різноманітними показниками: безперервність, прихованість, оперативність, стійкість. Але ці показники та побудовані моделі для ї оцінки не відображають особливості одночасно інформаційних відношень і матеріальних стосунків елементів системи під час вирішення завдань управління. Це обгрунтовується наступними положеннями [13].

1. Якщо критерій є засобом оцінки напрямку приведення керованої системи до необхідного стану, то для процесу управління головне це керованість COTC. А керованість (для COTC: англ. Controllability/Manageability) - це властивість системи управління та об'єкта управління, яке описує можливість перевести систему з одного статичного стану в інший. Керованість може розглядатися відносно будь-якого показника управління, наприклад, стійкості, прихованості, оперативності та ін. Така невизначеність або багатокритеріальність значно ускладнює формалізацію і розв 'язування самої задачі управління.

2. Якщо якість управління залежить від організованості відношень між елементами системи під час вирішення завдань, то іiі відсутність в умовах впливу на критичний елемент може призвести до того, що система буде некерованою [14], а це не зовсім так. СОТС може набувати стан частково керованої, слабко керованої і т. і.

3. Якщо вважати, що досягнення необхідного стану обмежене часом, то якість управління залежить від оперативності вирішення завдань, а іiі відсутність в умовах впливу на критичний елемент може призвести до того, що система буде некерована, а це не зовсім так.

4. Якщо рівень стійкості - нижня межа ефективності функціонування системи під час певного рівня організованості системи для досягнення заданої мети, то ресурси системи спочатку розподіляються для досягнення потрібної стійкості в системі, а потім на підвищення ефективності їх застосування, тобто керованість залежіть тільки від ресурсів.

Розглянуте вказує на те, що оцінка функціонально-структурної реорганізації системи для виконання завдань вимагає застосування іншої моделі, яка відображає ієрархію властивостей адміністративного управління та їх показників. Тому необхідно дослідити іiї сутність і визначити місце застосування такої моделі. Вважатимемо, що в СОТС для досягнення будь-якої мети існує наступний причиннонаслідковий ланцюг: потреба користувача - вимога до системи (мета) - функція системи або ії елементів - структура відношень між елементами - накопичення і розподіл ресурсів (потреба - вимога або мета - функція - структура - ресурси). Введення такого ланцюга надає можливість ураховувати інформаційні відношення, матеріальні стосунки елементів системи і відображати їх місце в моделі. 
Тоді досягнення необхідної керованості на основі будь-якого показника системи стає загальною моделлю процесу адміністративного управління. Вона відображає можливість приведення керованої системи в заданий стан за допомогою керованого впливу. Математичні аспекти керованості та спостереження для лінійної стаціонарної системи розглянути на основі теорії Р.С. Калмана [16]. Для динамічних систем це вимагає вирішення питання оцінки організованості. Для розгляду моделі організованості динамічних систем звернемо увагу на частину ланцюга “функція - структура - ресурси”, де проявляється функціонально-структурна реорганізація. Вона впливає на розподіл задач, що необхідно вирішити для досягнення певного завдання при наявності певних ресурсів сил і засобів системи.

Можна показати, що властивості “оперативність” і “стійкість” являються допоміжними для досягнення спочатку певної організованості, а потім керованості. Природно, що оперативність характеризує здатність своєчасного досягнення певної цілі в заданому факторному просторі. Врахувавши, що стійкість акцентує увагу з точки зору якості управління об'єктом, пропонується введення синергетичного, більш широкого змісту стійкості, як здатності будь-якої системи в процесі розвитку зберігати цілісність і самоорганізацію цієї системи, забезпечувати іiï розвиток без криз, прагнення до самозбереження, посилання на яке можна знайти в бібліографії [12].

Згідно 3 метою даної статті розглянемо більш конкретно процес організації. Поняття організація визначає процес створення внутрішньої упорядкованості, погодженості (порядку) і взаємодії елементів (сил і засобів) системи, які спільно реалізують програму або мету, і взаємодіють на основі визначених правил або процедур [4]. Це свідчить про те, що таке поняття припускає досягнення мети, моделлю якої $є$ керованість, яка в свою чергу повинна базуватися на наявності деякого рівня організованості. Тобто властивість організованість повинна фіксувати динамічні закономірності функціонування, поведінки і взаємодії елементів в структурі системи. На основі цього сформуємо зміст поняття організованість.

Під поняттям “організованість” СОТС пропонується розуміти здатність певної (визначеної) структури системи бути готовою до виконання заданої функції з потрібною якістю в заданому факторному просторі. Організованість СОТС проявляється в наступних аспектах.

По-перше, організованість характеризує внутрішню упорядкованість, що полягає в узгодженості сил і засобів функціонально самостійних (самоврядних) підсистем 3 визначеною структурою відносно досягнення заданої системної мети на основі визначених правил або процедур їх взаємовідношень. Цей аспект суттєвий на етапі створення СОТС та її еволюційного удосконалення під час іiї реорганізації, тобто у випадку, коли СОТС розглядається в якості ОСКІ.
По-друге, організованість СОТС проявляється в результатах виконання поточних завдань, які формулюються для СОТС вищим органом управління. Для вищого органу управління суттєвим показником організованості СОТС $€$ ймовірність виконання поставлених завдань. Організованість СОТС вважається тим більшою, чим ближче ймовірність наближається до 1 (важлива також вартість виконання завдань, але ця характеристика СОТС та їі врахування в цій публікації не розглядається).

Наступним кроком є визначення кількісної оцінки організованості СОТС. Для цього, з точки зору керівника всієї системи управління під час реорганізації, необхідно враховувати типову “технологію” виконання завдань. Вона полягає в тому, що організаційна ланка управління розподіляе отримане завдання А на сукупність узгоджених між собою завдань $\mathrm{A}_{1}, \ldots \mathrm{A}_{\mathrm{k}}$, які необхідні для виконання завдання $\mathbf{A}$, кожна 3 яких виконується елементами виконавчої ланки системи. Кожне завдання $\mathrm{A}_{1}, \mathrm{~A}_{2}, \ldots \mathrm{A}_{\mathrm{k}}$ може бути виконане 3 певною ймовірністю. Ймовірність виконання завдання $\mathrm{P}_{\mathrm{A}}$ пов'язана 3 ймовірністю виконання окремих завдань $\mathrm{P}_{\mathrm{Ai}}$, де $\mathrm{i} \in 1, \ldots, \mathrm{k}$ відображає номер завдання в рамках визначеної кількості $\mathrm{k}$. У загальному випадку $\mathrm{P}_{\mathrm{Ai}}, \epsilon$ умовною величиною, оскільки можливості виконання різних завдань пов'язані між собою. Найпростіший випадок відповідає незалежності умов виконання різних завдань, коли

$$
\mathrm{P}_{\mathrm{A}}=\prod_{\mathrm{i}=1}^{\mathrm{k}} \mathrm{P}_{\mathrm{Ai}}
$$

Варіанти розподілу завдань між виконавцями складають основу для прийняття рішення на виконання завдання системою управління. Згідно 3 цим рішенням визначається розподіл ресурсів сил і засобів. Доцільність рішення визначається величиною ймовірності $\mathrm{P}_{\mathrm{A}}$, яка досягається внаслідок його прийняття. Невизначеність виконання завдання $\mathrm{N}_{\mathrm{A}}$ визначається відхиленням ймовірності $\mathrm{P}_{\mathrm{A}}$ від 1: $\mathrm{N}_{\mathrm{A}} \rightarrow \Delta \mathrm{P}_{\mathrm{A}}=1-\mathrm{P}_{\mathrm{A}}$. Невизначеність $\mathrm{N}_{\mathrm{A}}$ тим більша, чим менша величина $\mathrm{P}_{\mathrm{A}}$. Враховуючи це, пропонується за оцінку невизначеності приймати величину, зворотну ймовірності. Оскільки значення $\mathrm{P}_{\mathrm{A}}$ повинно бути близьким до 1, для забезпечення лінійного зв 'язку між $\Delta \mathrm{P}_{\mathrm{A}}$ і невизначеністю виконання завдання $\mathrm{N}_{\mathrm{A}}$ пропонується використовувати логарифмічній масштаб для зворотної величини $\mathrm{P}_{\mathrm{A}}$ :

$$
\mathrm{N}_{\mathrm{A}}=\log _{\mathrm{a}} \frac{1}{\mathrm{P}_{\mathrm{A}}}=-\log _{\mathrm{a}} \mathrm{P}_{\mathrm{A}} \cong \Delta \mathrm{P}_{\mathrm{A}} \text {. }
$$

Аналогічна оцінка поширюється на невизначеність виконання окремих завдань:

$$
\mathrm{N}_{\mathrm{Ai}}=\log _{\mathrm{a}} \frac{1}{\mathrm{P}_{\mathrm{Ai}}}=-\log _{\mathrm{a}} \mathrm{P}_{\mathrm{Ai}} \cong \Delta \mathrm{P}_{\mathrm{Ai}} .
$$

Якщо ймовірність виконання завдання встановиться на рівні 0,5 (поставлене завдання буде виконано або невиконано з однаковою ймовірністю), то величину невизначеності виконання завдання доцільно прийняти рівною 1. Відповідно основу лога- 
рифмів доцільно прийняти а=2, так що згідно з (1) i (2) невизначеність виконання завдання:

$$
\mathrm{N}_{\mathrm{A}}=-\sum_{\mathrm{i}=1}^{\mathrm{k}} \log _{2} \mathrm{P}_{\mathrm{Ai}} \text {. }
$$

У випадку, коли $\mathrm{P}_{2 \mathrm{i}} \rightarrow 1$, співвідношенню (3) може бути придана форма:

$$
\mathrm{N}_{\mathrm{A}} \approx-\sum_{\mathrm{i}=1}^{\mathrm{k}} \mathrm{P}_{\mathrm{Ai}} \cdot \log _{2} \mathrm{P}_{\mathrm{Ai}} \text {. }
$$

Співвідношення (4) по формі співпадає 3 співвідношенням для ентропії повідомлень, сформованих $з$ елементів алфавіту, кількість яких становить $\mathrm{k}$, а ймовірність вибірки $\mathrm{P}_{\mathrm{Ai}}$ [17]. Аналогічно, при умові $\mathrm{P}_{\mathrm{Ai}} \rightarrow 1$ праву частину співвідношення (4) можна називати ентропією вирішення завдання і вважати що невизначеність виконання завдання дорівнює ентропії вирішення завданнь.

\section{Висновок}

Відображено оцінку невизначеності - ентропію або кількість різноманітності. Н. Вінер визначив дуальність ентропія-інформація: «Як кількість інформації в системі $є$ оцінкою організованості системи, точно так ентропія $\epsilon$ оцінкою дезорганізованості системи; одне рівняється іншому, взятому з протилежним знаком». Тому такий підхід може використовуватися для оцінки функціонально-структурної реорганізації системи відносно виконання завдань для досягнення певної мети функціонування ОСКІ, як виду СОТС .

\section{Список літератури}

1. Катков Ю.І. Роль і місие інформачійної інфраструктури під час виникнення явища критичності організаційної системи / Ю.І. Катков, В.В. Вишнівський, С.О. Сєрих // Зв язок - 2017. - № 5/ - C 57-65.

2.Даник Ю.Г. Начіональна безпека: запобігання критичним ситуаціям: моногр. / Ю.Г. Даник, Ю.І. Катков, М.Ф. Пічугін. - Житомир : Рута, 2006.- 386 с.
3. Большой энииклопедический словарь: В 2-х m. / Гл. ред. А.М. Прохоров. - М.: Сов. Энцик., 1991. - 457 c.

4. Надежность и эффективность в технике: Справочник: в 10 m. /Ред. совет: В.С.Авдуевский (пред.) и др. М.:Машиностроение, 1988. Т. 3. - 328 с.

5. Саати Т.Л. Принятие решений: метод анализа иерархий / Т.Л. Саати. - М.: Радио и связь, 1993. - 278 с.

6. Месарович М. Основания общей теории систем / М. Месарович. - М.: Мир, 1966. -345 c.

7. Сетров М.И. Основы функциональной теории организации / М.И. Сетров. --Л.: Наука, 1972. - 320 c.

8. Математическая теория оптимальных процессов / Л.С. Понтрягин и др..-М.: Физматгиз, 1961.- 225 с.

9. Гуторова О.О. Адміністративний менеджмент: навч. посібник / О.О. Гуторова, О.М. Стасенко. - Харків: ХНАУ, 2014. $-383 c$.

10. Новіков Б.В. Основи адміністративного менеджменту / Б.В.Новіков, Г.Ф. Сініок, П.В. Круи. - Київ : Центр навч. л-ри, 2004. - 560 с.

11. Райченко А.В. Административный менеджмент : учебник / А.В. Райченко. - М.: ИНФРА-М, 2007. - 416 c.

12. Пригожин И. Порядок из хаоса: Новый диалог человека с природой / И. Пригожин, И. Стенгерс. - М.: Прогресс, 1986. - 188 c.

13. Попов Г.Х. Проблемы теории управления / Г.Х. Попов. - М.: Экономика, 1974. - 320 c.

14. Ляпунов А.А. Проблемы теоретической и прикладной кибернетики / А.А. Ляпунов. - М. :Наука, 1980. - 336 с.

15. Катков Ю.І. Очінка прочесів реорганізаиї системи з критичною інфраструктурою/ Ю.І. Катков, В.В. Виинівський, С.О. Сєрих // Зв язок - 2017. - № 6. - С. 57-65.

16. Кальман Р.Э. Об общей теории систем управления // Тр. 1 конгр. ИФАК, т.2, АН СССР, 1961. - 245 с.

17. Шеннон К. Работа по теории информатики и кибернетики. - М., Из-во иностр. лит., 19632.- 832 с.

Надійшла до редколегії 16.01.2018

Рецензент: д-р техн. наук, проф. М.К. Жердєв, Військовий інститут телекомунікацій та інформатизації імені Героїв Крут, Київ.

\section{ОЦЕНКА ПРОЦЕССОВ ФУНКЦИОНАЛЬНО-СТРУКТУРНОЙ РЕОРГАНИЗАЦИИ ОРГАНИЗАЦИОННО-ТЕХНИЧЕСКОЙ СИСТЕМЫ}

\section{В.В. Вишневский, А.П. Бондарчук, Ю.И. Катков, С.А. Серых}

Рассматривается сущность процесса реорганизации сложной организационно-технической системы и вопросы оценки административного управления при выполнении задач на всех этапах цикла управления учреждением. Рассматриваются аспекты организованности сложной организаиионно-технической системы. Предлагаются модели управления функционально-структурной реорганизацией системы. Определяются критерии организованности в процессе реорганизации. Обосновывается в качестве мерила организованности сложной организационно-технической системы энтропия (количество разнообразия решения задач). Предоставляются математические модели организованности.

Ключевые слова: организационно-техническая система, критическая система, управление, вызовы, угрозы, реорганизачия, управляемость, энтропия.

\section{THE ESTIMATION PROCESS OF REORGANIZATION OF STRUCTURE AND FUNCTIONS OF THE ORGANIZATIONAL AND TECHNICAL SYSTEM}

V.V. Vyshnivskyi, A.P. Bondarchuk, Yu.I. Katkov, S.O. Serikh

This paper deals with controllability properties complex organizational - technical system. The evaluation of administrative management in the performance of tasks at all stages of the management cycle is considered. The aspects of organization of a complex organizational - technical system are considered. Models of management models for functional and structural reorganization of the system are given. The criteria of organization in the process of reorganization are determined. The entropy (the amount of diversity in the solution of problems) is justified as a measure of the organization of a complex organizational - technical system. Mathematical models the amount of diversity in the solution of problems is provided.

Keywords: organizational and technical system, critical system, management, challenges, threats, reorganization, controllability, entropy. 